This item was submitted to Loughborough's Research Repository by the author.

Items in Figshare are protected by copyright, with all rights reserved, unless otherwise indicated.

\title{
How mythical markets mislead analysis: an institutionalist critique of market universalism
}

PLEASE CITE THE PUBLISHED VERSION

https://doi.org/10.1093/ser/mwy049

\section{PUBLISHER}

(c) The Authors. Published by Oxford University Press and the Society for the Advancement of SocioEconomics.

\section{VERSION}

AM (Accepted Manuscript)

\section{PUBLISHER STATEMENT}

This is a pre-copyedited, author-produced version of an article accepted for publication in Socio-Economic Review following peer review. The version of record HODGSON, G.M., 2019. How mythical markets mislead analysis: an institutionalist critique of market universalism. Socio-Economic Review, In Press is available online at: https://doi.org/10.1093/ser/mwy049

\section{LICENCE}

CC BY-NC-ND 4.0

\section{REPOSITORY RECORD}

Hodgson, Geoff. 2019. "How Mythical Markets Mislead Analysis: An Institutionalist Critique of Market Universalism”. Loughborough University. https://hdl.handle.net/2134/36936. 


\title{
How Mythical Markets Mislead Analysis: An Institutionalist Critique of Market Universalism
}

\author{
Geoffrey M. Hodgson
}

20 December 2018

To be published in Socio-Economic Review

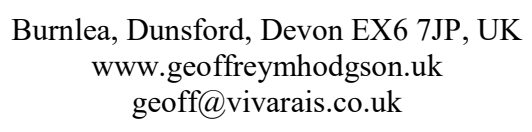

KEY WORDS: markets, market universalism, market fundamentalism, institutional economics, neo-liberalism

JEL classifications: B25, B40, B52, D52, P10,

10,100 words, inclusive of references

\begin{abstract}
Market universalism refers to the non-metaphorical tendency to use the term market to describe a wide variety of arrangements or processes in the real world. Using institutional criteria, this paper establishes some minimal necessary features of a market, to show that some particular arrangements are not markets. For example, while mechanisms of competition and interaction are ubiquitous, ordinary conversation is not literally a 'market for ideas' and much of politics is not literally a 'political market'. Markets are not and cannot be universal. Yet market universalism overlooks missing markets, the theory of which implies that we are in a world of second-best solutions and that markets are not necessarily the answer to every economic problem. Also, by reducing politics to a form of 'market' economics, market universalism downplays the distinctive, non-market nature of the political and legal spheres, and corrodes the conceptual separation of civil society from the state.
\end{abstract}




\section{Introduction}

There has been much debate over the alleged virtues or vices of markets, and over the extent to which they should be accepted in a modern economy. ${ }^{1}$ This paper is not about this normative debate. It offers neither a critique nor a defence of markets. Instead, the primary concerns of this paper are descriptive and analytic.

Here the term market universalism is used to refer to the prolific, non-metaphorical use of the term market to describe a large number of varied arrangements or processes in the real world. Some authors suggest that markets are ubiquitous, or nearly so, as if they were the universal essence of unhindered human interaction. This is primarily a descriptive rather than a normative stance, but, as shown below, it can lead to normative policy temptations. ${ }^{2}$

Karl Polanyi $(1977$, pp. 6, 10) rightly pointed out that 'equating the human economy in general with its market form' was a serious error. ${ }^{3}$ He explained that phenomena such as reciprocity and gift-giving are different from market relations. Against this, market universalism describes political elections as markets, and perceives markets for ideas, laws, marriages and much else. Margaret Radin (1996) noted the tendency toward 'universal commodification' in both language and reality. Market universalists misuse the term market to describe some arrangements which, by reasonable minimal criteria, are not really markets at all: they are mythical markets.

Hence market universalism is different from market fundamentalism. The latter is typically defined (mostly by critics, such as Soros 1998, 2008, Stiglitz 2008 and Block and Somers 2014) as the belief that unfettered markets generally bestow welfare and prosperity. Note that market fundamentalism does not imply market universalism: one can advocate markets fervently without positing them as already universal. In fact, market universalism weakens market fundamentalism: if markets are already omnipresent then their promotion loses much normative potency. This paper proposes that both supporters and opponents of market fundamentalism should reject market universalism.

A problem with market universalism that its use of the word market becomes so pliable that it is difficult to identify adequately any non-market processes or arrangements. For example, writers such as Peter Boettke et al. (2004) rightly emphasized that markets vary in the natures and institutional structures. But they open the door to market universalism by their thrice repetition of the claim that 'markets are ubiquitous', adding 'like weeds they crop up wherever the opportunity arises ... markets are omnipresent' (Boettke et al. 2004, pp. 71, 73, 74, 83). But they did not tell us clearly what kinds of arrangements or processes are not markets. This is a frequent omission by market universalists. This definitional lacuna creates problems, as Eckehard Rosenbaum (2000, p. 457) pointed out:

\footnotetext{
1 The author is very grateful to Zoltán Ádám, Richie Adelstein, Bruno Amable, Jens Beckert, Fred Block, Hulya Dagdeviren, Matthias Klaes, János Kornai, Richard Langlois, Richard Lipsey, Deirdre McCloskey, Károly Mike, Philip Mirowski, Richard Nelson, John O’Neill, Martin Ricketts, Viktor Vanberg, anonymous referees, and several participants at presentations in Corvinus University Budapest (Hungary), the World Interdisciplinary Network for Institutional Research 2018 Conference in Hong Kong, the University of Hertfordshire (UK), Buckingham University (UK) and Anglia Ruskin University (UK) for comments on earlier drafts of this paper.

2 The term 'market universalism' was used by Pettman (2001) but invested with different connotations. ${ }^{3}$ Despite its importance, Karl Polanyi's (1944) attempt to argue that there are limits to markets has major problems
and inconsistencies (Hodgson 2017).
} 
Economists or politicians who endorse markets must specify where and when a market does in fact exist and where and when it is absent. Unless they are able to do so, their policy recommendations could neither be evaluated in relation to the purported objectives of market creation nor tested with respect to the empirical implementation of the market.

Any normative case for markets needs to identify more clearly the instances of their absence, instead of merely pointing to impediments or restraints. Obversely, if anyone wishes to identify spheres where markets should be excluded, then they need to explain what a market is, and what might take its place.

Some market universalists identify exchange with choice and markets with competition. But these features exist outside markets. We choose what clothes to wear or what books to read. Competition covers any contest, including sports or games. Clearly, not all choice or competition involves exchange or markets. We need additional criteria, particularly to identify what are not markets. These criteria concern the nature of the institutions involved.

This is an institutionalist critique of market universalism because it treats genuine markets and trade as necessarily guided by systems of legal or other rules. But, as shown below, among the foremost proselytizers of market universalism are two institutional economists who won Nobel prizes for their work. One of the purposes of this article to rectify this major defect found in the writings of highly influential authors in the sphere of institutional research.

The following section shows how the use of terms such as 'political market' and 'market for ideas' has risen dramatically since the 1960s. Section three discusses the problematic concept of the market and demonstrates a huge diversity of definitions. Section four establishes some minimal institutional conditions for their existence. Section five gives prominent examples where the term market has been attached to phenomena that are not really markets by these minimal criteria. Section six discusses some analytic consequences of market universalism, particularly the neglect of missing markets and their consequences. ${ }^{4}$ Section seven examines some policy temptations within market universalism, most importantly some possible consequences of its dissolution of the political into the economic sphere. Section eight concludes the essay.

\section{The rise of the m-word}

The use of the term market to describe a wide variety of socio-economic arrangements seems a quite recent development. To assess this shift in terminology, attention is focused on the terms 'market for ideas' and 'political markets' (and close variants). These two instances are discussed in more detail in section five. First consider their spectacular rise from obscurity.

Figure 1 shows the rise on the use of the terms 'market for ideas' and 'political markets' (and close variants) in all JSTOR-listed journal articles in English in economics, sociology or political science. ${ }^{5}$ These terms have not only increased in frequency but have been taken up by influential social scientists, including two Nobel Laureates.

\footnotetext{
4 The term missing market simply means that a sphere of activity is not subject to market arrangements. Logically it entails no normative claim: it does not imply that markets should fill the void.

5 JSTOR is a large searchable database of established journals. The search terms were 'market* of/for ideas' and 'political market*', where '*' is a wildcard, to capture plurals and the word 'marketplace'. The search was performed on 26 March 2018.
} 
The usage of these two terms increased rapidly after the 1960s. The term 'political markets' (or similar) peaked at 474 articles in the 1990s while 'market for ideas' (or similar) reached 343 occurrences in the first decade of the twenty-first century. If we consider that the overall number of published articles was increasing, the relative effect is still very pronounced. The percentage frequency of the terms 'market for ideas' (or similar) and 'political markets' (or similar) both more than doubled from the 1960s to the 1970s, and it continued to rise dramatically, at least until the 1990s.

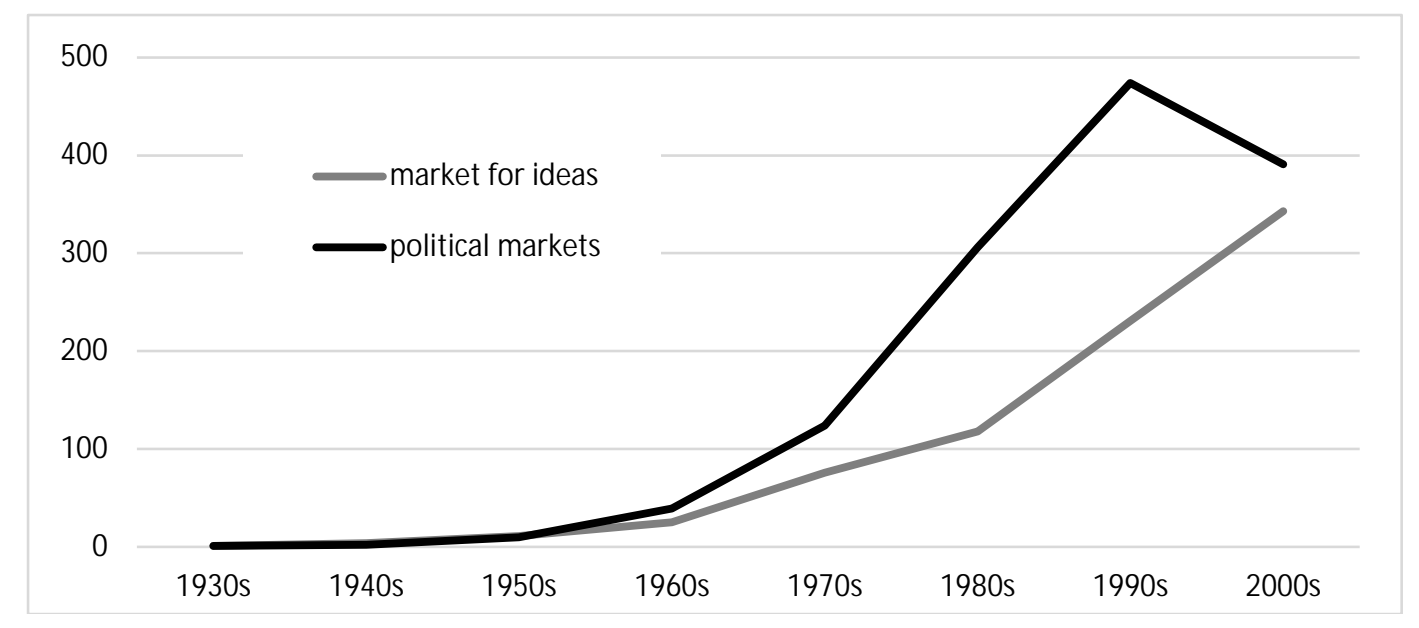

\section{Figure 1: Number of JSTOR articles in journals in English in economics, sociology or political science using terms like 'market for ideas' and 'political markets'}

The dramatic rise since the 1960s may be associated with the increasing influence of the strong pro-market 'neo-liberal' ideologies associated with Friedrich Hayek, Milton Friedman, the Mont Pelèrin Society and the University of Chicago. Historians of neoliberalism agree that its spectacular rise of influence dates from the 1970s (Mirowski and Plehwe 2009, Burgin 2012, Stedman Jones 2012, Mirowski 2013). The correlation in timing seems too strong to be coincidental. In particular, Philip Mirowski (2013, p. 77) has claimed that 'the marketplace of ideas' is 'a neoliberal notion if ever there was one.'

It is far beyond the scope of this article to explore the meanings or history of neo-liberalism. ${ }^{6}$ While the rising use of terms like 'market for ideas' and political markets' may be associated with the ascent of so-called neo-liberalism, the interrogation of this hypothesis is left for an adequate study elsewhere.

\footnotetext{
6 Some authors have questioned whether sufficient precision and restraint can be restored to the term neoliberalism. On its ambiguities see Burgin (2012, pp. 57, 82), Venugopal (2015) and Hodgson (2019b). On the other hand, Amable (2011), Dardot and Laval (2017) and others have proposed that it can be given an adequately precise meaning. This dispute cannot be resolved here.
} 
Metaphor is legitimate and unavoidable in science. It is possible that much use of the m-word is purely metaphorical. Even so, the remarkable rise in use of the market metaphor since the 1960s would require some explanation.

It will be shown below that some highly influential, usages of these terms are not associated with warnings that these terms are intended to be merely metaphorical. Instead, their authors suggest that what are described as markets really are markets.

Of course, the very rise of so-called neo-liberalism has been associated with the actual and pursued extension of the role of the market in the economy, including the extension of genuine markets for intellectual property, and so on. There has also been a notable rise in the use of contracted services - by lobbyists, advisors, consultants and others - in the political sphere. Hence, to a degree, rising usages of these terms may reflect real-world phenomena. But it is still the case that highly influential usages of these terms are not confined to these cases where genuine markets or contracts are involved.

Table 1 illustrates the logical possibilities. A phenomenon $P$ is described as a market. In reality, $P$ may be, or may not be, a market. Our focus is not on the veracity of claims of the form $\mathrm{O} 1$ or $\mathrm{O} 2$. If it were, then we would need a full definition of a market. We are also unconcerned by the (possibly legitimate but literally false) metaphorical usage O3.

\begin{tabular}{|c|c|c|c|}
\hline Description & Reality & Descriptive options & Evaluation \\
\hline \multirow{2}{*}{$\begin{array}{c}\text { Phenomenon } P \\
\text { is described as a } \\
\text { market }\end{array}$} & $P$ is a market & $\begin{array}{c}\text { O1. The descriptive use of } \\
\text { market is metaphorical }\end{array}$ & $\begin{array}{c}\text { The metaphor is also } \\
\text { descriptively valid }\end{array}$ \\
\cline { 2 - 4 } & P is not a market & $\begin{array}{c}\text { O2. The descriptive use of } \\
\text { market is literal }\end{array}$ & Descriptively valid \\
\cline { 2 - 4 } & O3. The descriptive use of & $\begin{array}{c}\text { Can be useful or } \\
\text { misleading }\end{array}$ \\
\cline { 2 - 4 } & $\begin{array}{c}\text { O4. The descriptive use of } \\
\text { market is literal }\end{array}$ & Descriptively invalid \\
\hline
\end{tabular}

Table 1: General options with the use of the descriptive term market

The critical attention in this paper is solely on the non-metaphorical descriptive option $(\mathrm{O} 4)$. For effective rebuttal of false claims (O4), two conditions must be satisfied. First, it must be shown that there is no sign of metaphorical intent. Second, it must be shown that phenomenon $P$ does not qualify as a market by minimal criteria. Because we are focusing on $\mathrm{O} 4$ only, which requires demonstrations of non-existence (rather than confirmations of existence, as with O2), then all that are required are some minimal (necessary but not sufficient) criteria for a market. It is thus unnecessary for our purposes here to provide a full definition of a market. Furthermore, because of a variety of current definitions, it would be difficult to establish one with adequate 
consensus support. The following section demonstrates this definitional diversity and section four outlines minimal criteria for the existence of a market.

\section{The slippery idea of the market}

Nobel Laureate Douglass North (1977, p. 710$)$ noted perceptively: 'It is a peculiar fact that the literature on economics and economic history contains so little discussion of the central institution that underlies neo-classical economics - the market.' Similarly, Nobel Laureate Ronald Coase (1988, p. 7) observed that 'in modern economic theory the market itself has an even more shadowy role than the firm.' The sociologist Pierre Bourdieu (2017, pp. 172-73) argued that economists are compelled to deploy some notion of a market but are symptomatically unable to provide a definition. They write about supply, demand and competition, and use the m-word in abundance, while often failing to signify what a market is. Even when it is defined, there are typically further problems and ambiguities. ${ }^{7}$

In ordinary language the word market typically has a narrow meaning: it refers to a place where commodities of a particular type or types are regularly traded. As Karl Polanyi (1944, p. 56) wrote: 'A market is a meeting place for the purpose of barter or buying or selling.' With the Internet, this 'place' may be virtual, as with eBay or Amazon. Such a narrow definition can distinguish markets from trade in general and from 'relational exchange' (Goldberg 1980). Economists often broaden this commonplace definition, but the degree of broadening varies enormously. For example, Alfred Marshall (1920, p. 324) quoted Augustin Cournot (1838, ch. 4) with approval:

Economists understand by the term Market, not any particular market place in which things are bought and sold, but the whole of any region in which buyers and sellers are in such free intercourse with one another that the prices of the same goods tend to equality easily and quickly.

Cournot's relatively narrow definition invokes what some economists call 'the law of one price': it applies when the degree of competition and the frequency of trade are sufficient to bring the prices of similar goods or services into convergence. But notably the institutional preconditions of trade, including laws of property and contract, were unmentioned by Cournot. Without specification of these historically specific institutional conditions, the temptation arose to treat markets as the universal ether of unconstrained human interaction. ${ }^{8}$

Marshall also approvingly quoted William Stanley Jevons $(1888$, p. 84) who wrote of the term market being 'generalized, so as to mean any body of persons who are on intimate business relations and carry on extensive transactions in any commodity.' This removed Cournot's definitional requirement that competition must be strong enough to lead to convergences of prices. It opened the door to the use of the term market to apply to any form of trade, even if infrequent and uncompetitive. Hence, much later, in a prominent textbook, Hugh Gravelle and Ray Rees (1992, p. 3) declared that 'a market exists whenever two or more individuals are prepared to enter into an exchange transaction'. Definitions of the market thus range from the everyday notion of a trading-place with high trading frequencies and substantial competition, to a concept applying to all exchange transactions, however infrequent or remote.

\footnotetext{
${ }^{7}$ On the nature of definitions in social science see Hodgson (2019a).

${ }^{8}$ By contrast, Weber (1968, vol. 1, pt. 1, ch. 2) recognized that markets entailed legal and customary rules, as well as competition between multiple buyers and sellers.
} 
Crucially, the terms 'transaction' and 'exchange' also require definition in these formulations. Such terms also have broader versus narrower meanings. Economists are often vague on the issue. In sociology, the extremely broad and general 'exchange theory' of George Homans (1961) and Peter Blau (1964) proposes that a wide range of activities - including giftgiving and interpersonal communications - are 'exchanges'. In modern social science, basic concepts such as exchange, contract and transaction cannot be taken for granted. Ambiguities and multiple usages allow for further slippages in connotation, affecting the meaning of the term market itself.

Sometimes, the broader and inclusive definitions are driven by a desire to make foundational concepts as general as possible. But if 'markets' become ubiquitous, then the door is opened to market universalism, where almost everything is regarded as a market.

In this vein, Mises (1949, p. 97) saw all action, even by an isolated individual, as 'exchange' - as a 'rational' attempt to swap inferior for superior circumstances. But, when he struggled alone to survive on his island, with whom did Robinson Crusoe 'exchange' rights to property? Who ensured that the agreement was enforced? By exchange, Mises meant any situation involving choice, even when one sole individual is involved.

In 1907, the sociologist Georg Simmel (2004, p. 81) described production as an 'exchange with nature'. One wonders who negotiates on nature's behalf, and whether she is satisfied with the deal. Again, a view of exchange was implied that could involve one human agent alone.

Douglas Allen (2015, p. 383) defined transaction costs as 'the costs of establishing and maintaining economic property rights,' where property rights were defined simply as 'the ability to freely exercise a choice.' This suggests that a 'transaction' can simply be a matter of the choice and control by one individual over an object. As with Mises's definition of 'exchange', such a strange 'transaction' need not involve more than one person. ${ }^{9}$

Most social scientists see competition as an important feature of markets. But competition also takes place in many different (and often non-commercial) contexts outside markets. Rational choice is also seen as important and ubiquitous, particularly by mainstream economists. But unless this is confined to the historically-specific Weberian notion of rational calculation on the basis of monetary values, words such as rationality and competition alone would sustain a much wider set of market notions.

In sum, while the term market is often used, its implied meaning is often vague and when it is specified it varies enormously. There is further variation on the assumed meaning of component terms such as transaction and exchange. Consequently, the word market varies in intended meaning from, at one extreme, the everyday meaning of a place of regular commodity exchange, to an approach, at the other extreme, that seems to admit any activity. This robs the notion of the market of much institutional texture and historical specificity. This diversity of usage makes it extremely difficult to establish a single consensus definition of a market.

Fortunately, however, our mission is different: instead of the currently problematic task establishing a consensus definition of a market, we need reasonable minimal criteria to determine what is not a market. The logic of this task is quite dissimilar, as elaborated in the next section.

\footnotetext{
${ }^{9}$ Leading economists of property rights regard property simply as control or possession (Alchian 1965, Barzel 1989). For contrasting views see Commons (1924), Cole and Grossman (2002), Heinsohn and Steiger (2013), Hodgson (2015a, 2015c) and Deakin et al. (2017).
} 


\section{Pinning down minimal institutional conditions for markets}

We need to pin down some minimal institutional elements. The requirement is not to define a market, but to establish some of the rudimentary conditions required for markets to exist. These minimal conditions help identify phenomena that are not markets.

A full and precise definition of a market would immediately become controversial because of the clash between broad and narrow definitions in the literature, as noted above. There is no attempt to posit a full definition of a market here. ${ }^{10}$ For the purposes of this essay, agreement on an adequate definition is unnecessary. Required instead is the establishment of some minimal, necessary, institutional characteristics to identify what are not markets.

Consider the following formal explanation of this focus on minimal conditions rather than a full definition. An adequate definition $(X)$ of a market would have the following form:

If a socio-economic phenomenon $P$ has all the characteristics $\left[x_{1}, x_{2} \ldots x_{\mathrm{n}}\right]$

(where $\left[x_{1}, x_{2} \ldots x_{\mathrm{n}}\right]=X$ ),

- then $P$ is a market.

There may be controversy about some of the required definitional elements $\left(x_{1}, x_{2} \ldots x_{\mathrm{n}}\right)$. Broader definitions of a market would remove some of these requirements from the list, to make the definition more inclusive. But assume that there are some very basic characteristics $\left(x_{1}, x_{2}\right.$ $\ldots x_{\mathrm{m}}$ ) (where $m<n,\left[x_{1}, x_{2} \ldots x_{\mathrm{m}}\right]=\chi$, and hence $\chi \subset X$ ) that are common to all judicious definitions. Consequently:

If a socio-economic phenomenon $P$ lacks one or more of subset characteristics $\left[x_{1}, x_{2} \ldots x_{\mathrm{m}}\right]$ (where $m<n,\left[x_{1}, x_{2} \ldots x_{\mathrm{m}}\right]=\chi$, and $\chi \subset X$ ),

- then $P$ is not a market.

Instead of defining markets, our aim here is to identify some phenomena that, by reasonable criteria, are not markets. Hence our task is not to specify $\left[x_{1}, x_{2} \ldots x_{n}\right]$ but to identify a suitable (smaller) subset $\chi=\left[x_{1}, x_{2} \ldots x_{\mathrm{m}}\right]$. This undertaking should be easier and less controversial. If only one of the characteristics $\left[x_{1}, x_{2} \ldots x_{\mathrm{m}}\right]$ is absent then the phenomenon in question is not a market. Hence the task is to establish not $X$ but $\chi$.

A key precondition of a (broadly-conceived) market is the existence of multiple traders who are interacting and communicating with some shared understandings. The traders are capable of entering into agreements with others to supply assets or services in exchange for money or other assets. But (even with illegal markets) there need to be shared rules to determine what constitutes a mutually validated (written or verbal) agreement.

These rules do not have to be written down and they do not need to be laws. It is accepted that there can be illegal as well as legal markets. With legal markets, a combination of law and custom may determine the essential rules. With illegal markets the rules may be those of a mafia or a criminal gang. ${ }^{11}$ The difference is important, but it need not delay further our attempt to pin down some minimal and necessary institutional features of a market.

These are proposed minimal requirements $\chi^{*}$ for a market:

\footnotetext{
${ }^{10}$ Definitions of a market are suggested elsewhere (Rosenbaum 2000, Hodgson 2008, 2015a).

11 See Schelling (1984), Thornton (1991), Boettke et al. (2004), Dixit (2004), Becker et al. (2006), Beckert and Wehinger (2013), and Beckert and Dewey (2017) on illegal markets.
} 
A market entails a system of accepted rules, enabling multiple traders to enter into voluntary (written or verbal) agreements involving mutual obligations. These agreements are made through or between agents that can identify one another and communicate. ${ }^{12}$ Their agreed obligations are mutually understood to lead to the agreed delivery of goods, assets or services, in return for some agreed payment. This agreement involves allocations of mutually-endorsed rights to goods or services, according to mutually-accepted rules. ${ }^{13}$

These four italicized sentences performed the function of a subset $\chi$ with characteristics $\left[x_{1}, x_{2}\right.$ $\ldots x_{\mathrm{m}}$ ] above (where $m$ is substantially lower than $n$ ), to help us determine what is not a market. They are necessary but insufficient conditions for a market. They are not intended to constitute a full or adequate definition of a market.

There is some wiggle-room for varied interpretations here, particularly over terms such as accepted, rights, obligations and payment. Most definitions of this kind involve some degree of vagueness (Russell 1923). These issues are best addressed using concrete examples, as in the following section.

Note that agreements may have to be fulfilled over a shorter or longer period. There is no claim here that agreements have always to be enforced by external parties such as the state. Enforcement can be by reputation or by other means.

Using the above minimal criteria $\chi^{*}$, we can now examine cases where the minimal requirements are not satisfied, yet the phenomena are misleadingly described as markets. As we examine these cases it is clear that some market-related elements are present, such as competition (of a kind) and decentralized mechanisms of coordination. But these elements are insufficient, on their own, to warrant the description of a market.

\section{Mythical markets}

The term mythical markets refers to phenomena that are non-metaphorically described as markets, but are not markets, at least by the minimal requirements $\chi^{*}$ laid out in previous section. As noted above, Coase and North have been foremost critics of the failure to address the meaning and nature of markets. Yet ironically, they have also promoted two prominent devaluations of the meaning of the term market, by applying it to contexts that clearly fail to meet the minimal requirements above.

Consider the 'market for ideas'. Early users of the term include Michael Polanyi (1944, 1962). For him it was a useful metaphor among others: he also drew analogies from politics and religion. Like his brother Karl Polanyi (1944, pp. 41-43, 56, 68-72 etc.), Michael was clear that true markets use explicit prices. ${ }^{14}$

\footnotetext{
12 Note that this allows for the possibility that sellers or buyers are anonymous. It is sufficient that agents acting on their behalf can be identified.

13 Note that institutions are widely defined as systems of rules (North 1990a, Ostrom 1990, Knight 1992, Mantzavinos 2001, Hodgson 2015a, 2015b, 2019a).

14 M. Polanyi was a Keynesian liberal who also advocated substantial and redistributive inheritance taxes. Although he attended the founding meeting of the Mont Pèlerin Society in 1947, he parted company in the 1950s because of disagreements over principles and policy (Burgin 2012, p. 116).
} 
Aaron Director played a central role in the development of the Chicago school of economics. ${ }^{15}$ Director (1964) seemed to take the 'market for ideas' more literally. This could have been valid if he referred to trade in intellectual property. But his usage was much wider: he referred to free speech as a 'market for ideas'. Similarly, the US Supreme Court (1969, p. 395) ruled: 'It is the purpose of the First Amendment to preserve an uninhibited marketplace of ideas in which truth will ultimately prevail'. This usage too was not confined to intellectual property - as with Director (1964) it referred more broadly to free speech.

Coase (1974) and Coase and Ning Wang (2012, pp. 190-207) repeatedly described and advocated a 'market for ideas'. They gave no indication that their usage was intended to be metaphorical. Like Director, they used the term not primarily to refer to genuine markets in intellectual property, but to the need for 'freedom of speech and expression' and for 'the creation and transmission of knowledge' through educational institutions. For them, the 'market for ideas' was literal. ${ }^{16}$

Addressing 'the market for goods and the market for ideas' Coase (1974, p. 389) went even further: 'There is no fundamental difference between these two markets'. Given the nature of open conversation and free speech, this implies that contracts, agreements, prices or allocations of rights are not 'fundamental' to markets. ${ }^{17}$

Some ideas - as with patents and copyrights - may be traded, but most are not. We have ideas, but mostly they are not deemed objects of property under any accepted system of legal or other rules. The ordinary communication or debating of ideas does not involve agreements with the shared intention of creating obligations according to those rules. Much day-to-day conversation is not a transfer of specific rights. Much broadcasting of information does not identify the individual recipients of the broadcast - so agreements in this case are problematic.

Certainly, there is competition between ideas and there is competition on markets. But this does not mean that all transmission of ideas is via a market. Competition takes place outside markets, as on the sports arena, the TV game show or the battlefield. Competition as such does not necessarily imply the existence of contracts or markets.

Consider the term 'political market'. While some political services can be traded on genuine markets, and votes can be traded (illegally) in some countries, it is contestable that all voting and all politics can be regarded as markets. A relatively early use of the term was by W. Mark Crain in a leading economics journal. Crain did not confine his usage to contracted political services. Crain (1977, pp. 829-30) wrote twice: 'votes are exchanged for public-policy outcomes'. He referred to voters as 'buyers' and politicians as 'sellers', albeit in quotes. But quote marks are absent in his discussions of political property rights and of the vote market. He gave no indication that his use of exchange or market was intended to be metaphorical. ${ }^{18}$

15 Both Coase and Director were at the University of Chicago Law School and members of the Mont Pèlerin Society.

16 Coase and Wang (2012, pp. 190-207) repeated the phrase 'market for ideas' about thirty times, and the 'market for goods and the market for ideas ... together in full swing' was their main policy recommendation for contemporary China, neglecting other possible institutional reforms in land tenure, corporate law, finance, or the political system (Hodgson and Huang 2013).

17 See Mäki (1999) for further criticisms of Coase on this issue.

18 Much earlier, the Italian economist Pantaleoni (1911) considered the political system as a market with its own 'political prices' alongside the economic market. 
A literature emerged in the 1970s and 1980s that applied the term 'political market' both to voting in elections and to measures by lobbyists and pressure groups to gain the support and votes of politicians. North $(1990 \mathrm{a}, 1990 \mathrm{~b})$ joined this throng, making the important Coasean point that analysis of these 'transactions' should recognize the transaction costs involved. But North (1990b, p. 362) admitted: 'It is extraordinarily difficult to measure what is being exchanged in political markets and in consequence to enforce agreements. What is being exchanged are promises for votes.' Again, there was no indication by North that the usage of terms like market or exchange in such contexts was intended to be metaphorical.

In a rare case, Richard Hasen (1998) admitted that the term 'political market' is a 'metaphor'. He argued that it should not be pushed too far. But such qualifications are infrequent.

Alongside the increasingly fashionable use of market-derived language since the 1970s, there has been a big increase in institutionalized lobbying in major democracies (Kaiser 2009). Insofar as they genuinely compete and trade their services, these 'political markets' are real. But this does not necessarily mean that there are 'markets for votes'.

In many countries (including the US) it is illegal for a lobbyist to pay or to give gifts to a member of the legislature in return for his or her vote. Legal lobbying is an information service, rather than a contract for votes. But of course, there are many ways in which lobbyists use gifts or campaign contributions to sway the votes of legislators. Nevertheless, incautious rhetoric involving 'political markets' blurs the distinction between information services and bribery. If lobbying really creates a market for votes, then it is an illegal one. But if there is compliance with the law, then North is wrong: votes are not literally the objects of market-like exchange. ${ }^{19}$

In democracies under the rule of law, a vote by a member of the public for a politician or a party does not typically amount to an agreement that satisfies the minimal conditions $\chi^{*}$ of a market. The elected politician or party cannot normally identify all the individual voters who voted for them, so at least one of the minimal conditions for a market is violated. One is enough to prove the negative.

The manifesto of a political party is an indication of intent, not an enforceable contract. Typically, politicians cannot be sued for broken promises: the voter has no right of legal redress. A politician's promise is not an 'offer' which is 'accepted' by casting a ballot: no legally binding agreement is created, involving prices or anything else. The law normally prohibits payments in return for votes. If there were such a contract, then it would be tantamount to political corruption. Of course, in many countries the rule of law is imperfect. But the point here is not to deny that votes can be traded. Instead it is denied that voting always involves some market-like deal.

The notion of 'political market' is strangely indifferent between less corrupt democracies and others (such as India) where the (illegal) buying of popular votes and the votes of elected politicians is frequent (Mitra et al. 2017). The latter may legitimately be described as 'political markets' because (illegal) contracts for political services are involved. But this does not mean that the entire polity in every democracy is a political market.

Another example concerns the legal system, Bruce Benson and Eric Engen (1988) envisioned 'the legislative process as a market for laws' where interest groups 'pay' legislators for laws as 'products'. They put quotes around 'pay' but that did not inhibit their unequivocal treatment of

\footnotetext{
19 The question of de facto legal compliance (or non-compliance) is important for other reasons. There is evidence that compliance with the law has ethical and motivational force for many (but not all) people (Tyler 1990). Some consequences of this observation are explored in Hodgson (2015c).
} 
the legislature as a market (without quotes). But there are rarely any enforceable agreements, involving transfers of rights, between interest groups and legislators in this context. Furthermore, if an interest group successfully lobbies for a new law, then that 'product' applies to everyone who is subject to that legal system, not just the lobbyist. It is a strange market where one purchase leads to its delivery to all.

There is another problem here. What is the system of rules under which these supposed 'contracts' between legislators and interest groups are formed and enforced? Markets themselves are institutions involving rules. Hence a 'market for laws' would require supra-legal institutions with their own (legal or other) rules. Supposedly then, we would need markets for markets-for-laws, or markets for meta-rules. This would go on without end - a problem of infinite regress. ${ }^{20}$

These examples show that the non-metaphorical use of the term market has spread to all sorts of phenomena that, by the requirements $\chi^{*}$ laid out above, should not reasonably be described as markets. ${ }^{21}$

\section{Analytical problems with market universalism}

The first and most obvious analytical defect of market universalism is that it impoverishes the concept of a market. The market may be defined in different ways (Rosenbaum 2000, Hodgson $2008,2015 a)$ and no one definition is being promoted here. But it is reasonable to suggest that markets always involve rights and agreements, according to mutually accepted rules. Hence the appeal to the minimal requirements $\chi^{*}$ above. ${ }^{22}$

This section does not consider the moral limits to market arrangements or processes. These have been energetically debated elsewhere. ${ }^{23}$ The primary focus is analytic.

By the minimal stipulations above, markets involve rules. If 'markets for laws' (Benson and Engen 1988) were universal, then there would be markets for all those rules that are required for functioning markets (for laws). As noted above, this would then require a meta-market for market rules, and a meta-meta-market for those rules, and so on - an infinite regress. By this logic, markets would become more than universal - they would be infinite. It is difficult to imagine how a system of infinite markets could exist, especially as regular trade in infinite markets would require an infinite number of contracts. There must at some point be market rules that are not traded on markets. Consequently, there cannot be markets for all laws.

\footnotetext{
20 Pejovich's (1994) proposed a 'market for institutions'. But he avoided the problem of infinite regress by suggesting a given institutional framework within which competition for second-level institutions should take place. The remaining problem in his account is the contentious description of this arrangement as a market.

${ }^{21}$ For further examples of the questionable use of the term market see Hodgson (2015a).

22 There is also a very widespread tendency in both economics and sociology to use the commercial language of money and trade to describe phenomena that are neither traded nor have discernible monetary value. The boldest of these is 'social capital' (Bourdieu 1986). This was abetted by the shift of meaning of 'capital' from a monetary phenomenon to any durable and useful entity or arrangement (Cannan 1921, Fetter 1930, Hodgson 2014, 2015a).

23 See Radin (1996), O’Neill (1998), Satz (2010) and Sandel (2012). Despite its title, Markets without Limits by Brennan and Jaworski (2016) does not claim that markets are ubiquitous. Instead they argue that any action that is moral, may morally be done for money. We need not evaluate this argument here.
} 
Émile Durkheim (1984, p. 158) also famously pointed to the necessary existence of rules beyond markets themselves. He argued in 1893 that contracts require preconditions that cannot themselves be fully contracted: 'in a contract not everything is contractual'. All markets entail rules, and not all rules can be traded.

There are also good practical reasons to prevent key services of the legislature and the judiciary from being traded, including those relating to property and markets. For example, if judicial rulings were for sale to the highest bidder, then the security of property rights and their exchanges would be undermined. Hence Michael Walzer (1983) established the need for 'blocked exchanges' in some spheres, excluding markets from politics, the legislature and the judiciary.

Through the use of patents, licenses, copyright and so on, some information can become intellectual property and traded on markets. But there would be problems if all information became tradeable property. The extension and subdivision of ownership in a densely interconnected knowledge economy can create an 'anti-commons' where extensively divided and interconnected rights - in a real world with positive transaction costs - obstruct investment and trade. The problem applies particularly to patents and other intellectual property and has become more severe in an increasingly knowledge-intensive economy (Heller 2008, Pagano 2014).

While much information and knowledge cannot readily be shared (because of tacitness, interpretative difficulty, or inaccessibility) much else can, and this can be of huge productive value. Over-restriction of the cheaply-acquired benefits of shared possession of non-rivalrous informational assets can generate remarkable inefficiencies. Consequently, the benefits of private and contractual provision of some information may be much less than the overall opportunity costs of charging a price for its use. A healthy market system itself depends on missing or incomplete markets for information.

Other markets are missing or incomplete. In today's developed market economies, most people work under an employment contract. But crucially, employment contracts are for a limited period of time into the future. We cannot legally trade our lives away in lifetime contracts. This would be tantamount to voluntary servitude.

There is some future contracting for labour power, such as when a student receives financial support from a company, in return for a commitment to work for some years in the firm. But the time period is typically a few years, amounting to a small fraction of the student's future working life. There are sometimes 'non-compete' agreements with skilled employees, that prevent them leaving a firm and working for a rival for a while. But these are still far short of lifetime contracts.

For this reason, under a market system with employment contracts, there can never be a complete set of markets for labour power. Although capitalism has meant a huge extension of property and markets, and it has made labour power a widespread commodity (as Marx emphasized), it has also, by freeing labour from servitude, sustained missing markets for labour futures. For there to be full futures markets for labour, all workers must be able to enter into contracts for every future instant in their expected working life. Such a complete curtailment of future discretion would be voluntary bondage. The uncertainties involved in modern, complex, dynamic economies make such extensive future contracting impractical.

There is in principle no satisfactory contractual solution, within a market economy with wage labour, to missing markets for labour power. Enforcing detailed and extended property and contracting rights, would limit the freedom of workers to quit their employment. Typically, 
workers are employed under a contract that allows exit, subject to notice of a few months. The short-term restriction of extended futures markets for labour is an important safeguard of the freedom of the employee.

Also, the future supply of labour power is not something that can be contracted at source, because babies cannot legally be farmed and sold as commodities within a system without slavery. Because they are not then objects of ownership, human infants and their future labour power are not themselves produced under market arrangements. In an economy with markets and free labour there are unavoidable missing markets for the original production of human resources. These markets could exist in other states of the world where slave markets operated, but they are ruled out (and consequently 'missing') in states of the world where wage labour is ubiquitous. ${ }^{24}$

The absence of futures markets for labour power creates a problem for the employer with the existing workforce. If the employer spends money on employee training and skill development, then this investment is lost when the worker leaves. As a result, without compensatory arrangements, employers might under-invest in human learning and education. As Alfred Marshall (1920, p. 565) pointed out: 'we meet the difficulty that whoever may incur the expense of investing capital in developing the abilities of the workman, these abilities will be the property of the workman himself: and thus the virtue of those who have aided him must remain for the greater part its own reward.' The implications of this have been explored in different ways. ${ }^{25}$

The problem of missing markets has been addressed within general equilibrium theory in the tradition of Kenneth J. Arrow and Gerard Debreu (1954). They investigated a heuristic model where 'markets' exist for all possible commodities, in all possible states of the world, for all points of time in the future. ${ }^{26}$

Later authors considered the possibility of missing markets in these models. A missing market is a market that could exist in some possible state of the world, but does not in fact exist. The term 'missing market' does not apply to markets that cannot ever exist. If one or more of the commodity-, state- and time-dependent markets is missing, then the absence of key information concerning prices on that missing market can cascade through the system and affect the overall outcome. The efficiency of other markets can be diminished.

Accordingly, Oliver Hart (1975, p. 442) showed that in 'an economy with incomplete markets ... the usual continuity and convexity assumptions are not sufficient to ensure the existence of equilibrium' and in such circumstances a market equilibrium may be Pareto suboptimal. Furthermore, 'if we start off in a situation where markets are incomplete, opening new markets

\footnotetext{
24 Sometimes babies are adopted in return for payment. Becker (1991, pp. 362 ff.) wrote of babies being sold. Posner (1994, p. 410) rightly responded: 'The term baby selling ... is misleading. A mother who surrenders her parental rights for a fee is not selling her baby; babies are not chattels, and cannot be bought and sold. She is selling her parental rights.'

25 Consider the literatures on 'non-firm specific human capital' and on training policies (e.g. Almazan et al. 2007, Thelen 2004).

${ }^{26}$ General equilibrium theory does not entail a normative, pro-market stance. Several key pioneers of the approach, including Oskar Lange and Kenneth Arrow, were socialists. Does general equilibrium theory constitute a form of market universalism? It would be so only if it was wrongly applied to mythical markets. This is not necessarily the case. A problem is that general equilibrium theory says little about the institutional details of such elemental phenomena as contracts or property.
} 
may make things worse rather than better. In this respect, an economy with incomplete markets is like a typical second best situation.' Likewise, Michael Magill and Martine Quinzii (1996) showed that missing markets can lead to absent or indeterminate equilibria in existing markets. ${ }^{27}$

Consequently, missing markets mean that we are in the world of 'second best' solutions. As Richard Lipsey and Kelvin Lancaster (1956) famously demonstrated, when one or more optimality conditions cannot be satisfied, it is possible that the next-best solution involves changing other variables away from the values that would otherwise be optimal. If it is infeasible to introduce a well-functioning market in any part of the system, then it is possible that the introduction of further market distortions or restrictions may partially counteract that omission, and lead to a more efficient outcome. There is no 'one-size-fits-all' policy solution where the removal of market impediments always brings efficiency or welfare. On the contrary, welfare outcomes of such interventions could be positive or negative - they would be dependent on context (Lipsey 2007).

Of course, general equilibrium theory has conceptual problems. But the point here is to show that mainstream economic theory has demonstrated that market solutions can be suboptimal when there are some things that are excluded from trade. Market universalism blinds its adherents to the existence of missing markets and to this mainstream conclusion.

Markets can be missing for different reasons. Some limits are universal: there cannot be markets for all information or all rules. Other markets are missing because of customary or legislative constraints. These constraints may be removable or irremovable, desirable or undesirable. The relevant problem with market universalism is that missing markets are often overlooked or denied.

\section{Policy temptations of market universalism}

Generally, it is difficult or hazardous to derive an ought from an is - a normative claim from an analytic claim. ${ }^{28}$ But statements concerning what things are, or how they work, can aid normative stances without logically entailing them. Market universalism is an analytic claim that is logically compatible with very different policy viewpoints.

However, the non-metaphorical misuse of the term market, to cover arrangements that are not best described in such terms, opens up pro-market normative possibilities. It removes conceptual barriers to pushing actual non-market arrangements towards genuine market mode. If most things are already seen as markets, or they are deemed to have an immanent tendency to become markets, then it would be less consequence to create more markets. Objections to the extension of markets are removed by the claim that existing arrangements are already markets. The temptation then is to ally market universalism with normative policies such as privatization and deregulation.

There is another temptation, with serious consequences. Through notions such as 'political markets' and 'markets for laws', market universalism conceptually dissolves the state and its legal system into a generally-marketized vision of society. They all become one and the same.

\footnotetext{
27 Magill and Quinzii (1996) saw missing markets as primarily a result of the limitations of the human psyche. They overlooked the important missing markets for labour power and future skills.

28 But pushed to the extreme, the is/ought and fact/value distinctions become challengeable (Putnam 2002).
} 
The state and law become additional markets alongside others. This temptation within market universalism is the marketization of society and the state, and the denial of the autonomy of politics. The consequent temptation is to downgrade all non-commercial justifications for democracy, law or social life. Everything is forced into the conceptual straitjacket of property and contract, and then evaluated in terms of profit and loss.

One of the achievements of Enlightenment thought - from John Locke and Adam Smith was the notion of civil society, which was distinguished from the state and meant more than mere trade or business. Although it is a contested concept, in most accounts civil society includes private business and markets, but it is not reducible to them. As well as trade unions and employer associations, it embraces many forms of social association (including recreation, religion and philanthropy) that are not necessarily driven by business interests. Civil society is important to develop local knowledge, sustain democracy and to organize powers to lobby or protest against governments. It is a vital sphere of action and organization between the individual and the state (Arato and Cohen 1992, Keane 1988, 1998, Kumar 1993, Gellner 1994).

Notwithstanding their interdependence, civil society is different from the state. Civil society is also irreducible to market relations, notwithstanding the inclusion of trade and business within its sphere. Market universalism doubly undermines these distinctions. First, civil society is reduced to matters of property and contract. Second, politics is seen as a market as well.

Making everything a market denies the autonomy of law and politics: everything is subsumed within the market zone. All forms of association are regarded as markets. Legal and political relations are reduced to the bland 'economic' facts of possession and exchange. Control over property becomes everything. Property moves from being a necessary condition of liberty, as in Enlightenment thought, to being necessary and sufficient for the same.

Also transformed is the prominent Enlightenment argument that the government must be legitimated by representative democracy, rather than by tradition or divine rule. Instead, the 'political market' helps to promote market criteria as the overriding means to legitimize democracy. Furthermore, democracy itself may be seen as secondary or expedient, especially when property or markets are under threat. By treating democracy as another market, a temptation is to regard markets and property as sovereign, rather than democracy.

Consequentially, market universalism enables something very different from other forms of liberalism. One may be tempted to call it neo-liberalism. As Mirowski (2009, p. 456) argued: 'Neoliberals seek to transcend the intolerable contradiction by treating politics as if it were a market and promoting an economic theory of democracy.'

Whether or not we use the label neo-liberal, clearly there is a prominent strain of modern thought that tries to justify everything in market-like terms. This suggests that there are no longer any worthwhile moral values or principles - including norms of justice or democratic behaviour - that cannot be given a market price.

We may briefly note an odd similarity with Marxism in this area, despite other major differences in theory and policy. Marxism does not entail market universalism: on the contrary, it emphasises the historical specificity of the market. But Marx and Engels did reduce civil society to economic matters of money and trade. Marx wrote in 1843: 'Practical need, egoism, is the principle of civil society ... The god of practical need and self-interest is money' (Marx and Engels 1975, p. 172). Civil society, for Marx, was the individualistic realm of money and greed. Hence Marx concluded that 'the anatomy of civil society is to be sought in political economy' (Marx and Engels 1962, vol. 1, p. 362). The analysis of the political, legal and social 
spheres was to be achieved with an economics based on the assumption of individual selfinterest.

Furthermore, the state, law and politics under capitalism were made analytically subservient to this dismembered, economistic vision of civil society. Accordingly, Frederick Engels wrote in 1886 that under capitalism 'the State - the political order - is the subordinate, and civil society - the realm of economic relations - the decisive element' (Marx and Engels 1962, vol. 2, pp. 394-5). Everything was deemed a matter of greed and commerce, to be understood through economic analysis.

Certainly, there are more sophisticated and less reductionist treatments by Marxists of civil society and the state, not least by Antonio Gramsci (Kumar 1993). But Marx and Engels, alongside recent market universalists, embraced economic reductionism. Everything turns into the economics of trade, eclipsing the autonomy of politics and law, and neglecting the vital importance of non-commercial interaction and association within civil society. ${ }^{29}$

\section{Conclusion}

While absolute precision is unattainable, ongoing vigilance in the use of terms and metaphors is vital. It is suggested here that there is much more involved than casual analogy to the persistent use of the term market to describe a huge range of economic, political, social and legal phenomena.

This paper shows that, by reasonable criteria, with minimal attention to the institutions and rules involved in a world of contracts a trade, the term market has been miss-used in instances such as 'markets for ideas', 'political markets', or 'markets for laws'. Often, these things are not true markets.

It is necessary to be clear what arrangements are not markets. Furthermore, it also must be understood that not everything can be traded on a market. In part this a matter of logic. To avoid an infinite regress, the rules and institutions used to constitute contracts and enable trade cannot themselves be the objects of market exchange.

Also, a market system with 'free' wage labour (in contrast to slavery) inevitably entails some missing futures markets for future labour power. Otherwise the worker would be bonded by contracts for life. Without remedial measures, this lacuna has multiple consequences, including, as Marshall (1920, p. 565) recognized, under-investment in on-the-job training in necessary skills. According to an important theoretical literature, the existence of missing markets means that attempted market solutions to inefficiencies cannot be guaranteed to work (Lipsey and Lancaster 1956, Hart 1975, Magill and Quinzii 1996, Lipsey 2007).

Although market universalism is not primarily a normative doctrine, it gives rise to major policy temptations. The most serious of these is the conceptual dissolution of the polity and the legal system into the 'economic' sphere of the 'market'. The boundaries between the polity, the economy and civil society become invisible. In particular, by treating democracy as a market, the temptation is to regard markets as more important than democracy.

\footnotetext{
29 Putnam's (2000) classic study of the erosion of American community life is highly relevant here. But the eager promotion of the language of social capital similarly and ironically nudges the realities of non-commercial interaction and association into the same economistic box (Hodgson 2014, 2015a).
} 
Market universalism assails the argument of Enlightenment thinkers that the major role of democracy is to legitimate government. Instead, everything is legitimated by free contract, and by the operation of unfettered markets in all spheres of human interaction, including within the state itself. In this way, by dissolving the distinction between civil society and the state, market universalism enables a radical break from other forms of liberalism, and from all other doctrines that recognise the relative autonomy of the political and legal spheres from the economy and from civil society.

Modern politico-economic systems entail numerous, varied, decentralized, systems of coordination. As Michael Polanyi (1962, p. 57) argued: 'the coordinating functions of the market are but a special case of coordination by mutual adjustment.' The polity is one such decentralized coordination system. ${ }^{30}$ The legal system is another. Civil society involves others. True markets are still others. While these may have common features at some abstract level, the detailed institutional structures and mechanisms are often very different. It is vital that these differences are not ignored, and that they are not all treated as markets.

\section{References}

Alchian, Armen A. (1965) 'Some Economics of Property Rights', Il Politico, 30, pp. 816829. Reprinted in Alchian, Armen A. (1977) Economic Forces at Work (Indianapolis: Liberty Press), pp. 127-149.

Allen, Douglas W. (2015) 'The Coase Theorem: Coherent, logical, and not disproved', Journal of Institutional Economics, 11(2), June, pp. 379-90.

Almazan, Andres, De Motta, Adolfo and Titman, Sheridan (2007) 'Firm Location and the Creation and Utilization of Human Capital', Review of Economic Studies, 74(4), October, pp. 1305-27.

Amable, Bruno (2011) 'Morals and Politics in the Ideology of Neo-liberalism', SocioEconomic Review, 9(1), pp. 3-30.

Arato, Andrew and Cohen, Jean L. (1992) Civil Society and Democratic Theory (Cambridge, MA: MIT Press).

Arrow, Kenneth J. and Debreu, Gerard (1954) 'Existence of an Equilibrium for a Competitive Economy', Econometrica, 22(3), pp. 265-90.

Barzel, Yoram (1989) Economic Analysis of Property Rights (Cambridge: Cambridge University Press).

Becker, Gary S. (1991) A Treatise on the Family, 2nd edn. (Cambridge, MA: Harvard University Press).

Becker, Gary S., Murphy, Kevin M. and Grossman, Michael (2006) 'The Market for Illegal Goods: The Case of Drugs', Journal of Political Economy, 114(1), February, pp. 38-60.

\footnotetext{
30 János Kornai suggested the term 'decentralized coordination mechanism' in an email to the present author on 17 April 2018, indicating that they may be universal in (large-scale) human societies, while markets are not. I have replaced 'mechanism' by 'system'.
} 
Beckert, Jens and Dewey, Matias (2017) The Architecture of Illegal Markets: Towards an Economic Sociology of Illegality in the Economy (Oxford and New York: Oxford University Press).

Beckert, Jens and Wehinger, Frank (2013) 'In the Shadow: Illegal Markets and Economic Sociology', Socio-Economic Review, 11(1), January, pp. 5-30.

Benson, Bruce L. and Engen, Eric M. (1988) 'The Market for Laws: An Economic Analysis of Legislation', Southern Economic Journal, 54(3), January, pp. 732-745.

Blau, Peter J. (1964) Exchange and Power in Social Life (New York: Wiley).

Block, Fred and Somers, Margaret (2014) The Power of Market Fundamentalism: Karl Polanyi's Critique (Cambridge MA: Harvard University Press).

Boettke, Peter J., Coyne, Christopher J. and Leeson, Peter T. (2004) 'The Many Faces of the Market', Journal des Economistes et des Etudes Humaines, 14(2), pp. 71-86.

Bourdieu, Pierre (1986) 'The Forms of Capital' in John G. Richardson (ed.) Handbook of Theory and Research for the Sociology of Education (New York: Greenwood), pp. 241258.

Bourdieu, Pierre (2017) Anthropologie économique - Cours au Collège de France 1992-1993 (Paris : Seuil).

Brennan, Jason and Jaworski, Peter M. (2016) Markets without Limits: Moral Virtues and Commercial Interests (London and New York: Routledge).

Burgin, Angus (2012) The Great Persuasion: Reinventing Free Markets since the Depression (Cambridge MA: Harvard University Press).

Cannan, Edwin (1921) 'Early History of the Term Capital', Quarterly Journal of Economics, 35(3), May, pp. 469-481.

Coase, Ronald H. (1974) 'The Market for Goods and the Market for Ideas', American Economic Review (Papers and Proceedings), 64(2), May, pp. 384-91.

Coase, Ronald H. (1988) The Firm, the Market, and the Law (Chicago: University of Chicago Press).

Coase, Ronald H. and Wang, Ning (2012) How China Became Capitalist (London and New York: Palgrave Macmillan).

Cole, Daniel H. and Grossman, Peter Z. (2002) 'The Meaning of Property Rights: Law versus Economics?' Land Economics, 78(3), August, pp. 317-330.

Commons, John R. (1924) Legal Foundations of Capitalism (New York: Macmillan).

Cournot, Augustin (1838) Recherches sur les principes mathématiques de la théorie des richesses (Paris: Hachette).

Crain, W. Mark (1977) 'On the Structure and Stability of Political Markets', Journal of Political Economy, 85(4), August, pp. 829-842.

Dardot, Pierre and Laval, Christian (2017) The New Way of the World: On Neoliberal Society, translated from the French edition of 2009 (London: Verso).

Deakin, Simon, Gindis, David, Hodgson, Geoffrey M., Huang, Kainan, and Pistor, Katharina (2017) 'Legal Institutionalism: Capitalism and the Constitutive Role of Law', Journal of Comparative Economics, 45(1), February, pp. 188-200. 
Director, Aaron (1964) 'The Parity of the Economic Market Place', Journal of Law and Economics, 7, October, pp. 1-10.

Dixit, Avinash K. (2004) Lawlessness and Economics: Alternative Modes of Governance (Princeton, NJ: Princeton University Press).

Durkheim, Émile (1984) The Division of Labour in Society, translated from the French edition of 1893 (London: Macmillan).

Fetter, Frank A. (1930) 'Capital', in Edwin R. A. Seligman and Alvin Johnson (eds) Encyclopaedia of the Social Sciences (New York: Macmillan), Vol. 3, pp. 187-90. Reprinted in the Journal of Institutional Economics, 4(1), April, pp.127-137.

Gellner, Ernest (1994) Conditions of Liberty: Civil Society and its Rivals (London and New York: Hamish Hamilton).

Goldberg, Victor P. (1980) 'Relational Exchange: Economics and Complex Contracts', American Behavioral Scientist, 23(3), pp. 337-52.

Gravelle, Hugh and Rees, Ray (1992) Microeconomics, 2nd edn. (Harlow: Longman).

Hart, Oliver D. (1975) 'On the Optimality of Equilibrium when the Market Structure is Incomplete', Journal of Economic Theory, 11(3), December, pp. 418-43.

Hasen, Richard L. (1998) 'The "Political Market" Metaphor and Election Law: A Comment on Issacharoff and Pildes', Stanford Law Review, 50(3), February, pp. 719-730.

Heinsohn, Gunnar and Steiger, Otto (2013) Ownership Economics: On the Foundations of Interest, Money, Markets, Business Cycles and Economic Development, translated and edited by Frank Decker (London and New York: Routledge).

Heller, Michael A. (2008) The Gridlock Economy: How Too Much Ownership Wrecks Markets, Stops Innovation, and Costs Lives (New York: Basic Books).

Hodgson, Geoffrey M. (2008) 'Markets', New Palgrave Dictionary of Economics, second edition, online (Basingstoke: Macmillan).

Hodgson, Geoffrey M. (2014) 'What is Capital? Economists and Sociologists have changed its Meaning - Should it be Changed Back?' Cambridge Journal of Economics, 38(5), September, pp. 1063-86.

Hodgson, Geoffrey M. (2015a) Conceptualizing Capitalism: Institutions, Evolution, Future (Chicago: University of Chicago Press).

Hodgson, Geoffrey M. (2015b) 'On Defining Institutions: Rules versus Equilibria', Journal of Institutional Economics, 11(3), September 2015, pp. 499-505.

Hodgson, Geoffrey M. (2015c) 'Much of the "Economics of Property Rights" Devalues Property and Legal Rights', Journal of Institutional Economics, 11(4), December, pp. 683709.

Hodgson, Geoffrey M. (2017) 'Karl Polanyi on Economy and Society: A Critical Analysis of Core Concepts', Review of Social Economy, 75(1), March, pp. 1-25.

Hodgson, Geoffrey M. (2019a) 'Taxonomic Definitions in Social Science, with Firms, Markets and Institutions as Case Studies', Journal of Institutional Economics, 15(2), April, forthcoming. 
Hodgson, Geoffrey M. (2019b) Is Socialism Feasible? Towards an Alternative Future (Cheltenham UK and Northampton MA: Edward Elgar), forthcoming.

Hodgson, Geoffrey M. and Huang, Kainan (2013) 'Brakes on Chinese Economic Development: Institutional Causes of a Growth Slowdown', Journal of Economic Issues, 47(3), September, pp. 599-622.

Homans, George C. (1961) Social Behaviour: Its Elementary Form (London: Routledge and Kegan Paul). Later edition 1974.

Jevons, William Stanley (1888) The Theory of Political Economy, $3^{\text {rd }}$ edn. (London: Macmillan).

Kaiser, Robert G. (2009) So Damn Much Money: The Triumph of Lobbying and the Corrosion of American Government (New York: Knopf).

Keane, John (ed.) (1988) Civil Society and the State (London: Verso).

Keane, John (1998) Civil Society: Old Images, New Visions (Cambridge: Polity).

Knight, Jack (1992) Institutions and Social Conflict (Cambridge: Cambridge University Press).

Kumar, Krishan (1993) 'Civil Society: An Inquiry into the Usefulness of an Historical Term', British Journal of Sociology, 44(3), September, pp. 375-395.

Lipsey, Richard G. (2007) 'Reflections on the General Theory of Second Best at its Golden Jubilee', International Tax and Public Finance, 14(4), pp. 349-64.

Lipsey, Richard G. and Lancaster, Kelvin (1956) 'The General Theory of Second Best', Review of Economic Studies, 24(1), December, pp. 11-32.

Magill, Michael and Quinzii, Martine (1996) Theory of Incomplete Markets (Cambridge, MA: MIT Press).

Mäki, Uskali (1999) 'Science as a Free Market: A Reflexivity Test in an Economics of Economics', Perspectives on Science, 7(4), pp. 486-509.

Mantzavinos, Chris (2001) Individuals, Institutions, and Markets (Cambridge and New York: Cambridge University Press).

Marshall, Alfred (1920) Principles of Economics: An Introductory Volume, 8th edn. (London: Macmillan).

Marx, Karl and Engels, Frederick (1962) Selected Works in Two Volumes (London: Lawrence and Wishart).

Marx, Karl and Engels, Frederick (1975) Karl Marx and Frederick Engels, Collected Works, Vol. 3, Marx and Engels: 1843-1844 (London: Lawrence and Wishart).

Mirowski, Philip (2009) 'Postface: Defining Neoliberalism', in Mirowski and Plehwe (2009, pp. 417-55).

Mirowski, Philip (2013) Never Let a Serious Crisis Go to Waste: How Neoliberalism Survived the Financial Meltdown (London and New York: Verso).

Mirowski, Philip and Plehwe, Dieter (eds) (2009) The Road from Mont Pèlerin: The Making of the Neoliberal Thought Collective (Cambridge MA: Harvard University Press). 
Mises, Ludwig von (1949) Human Action: A Treatise on Economics, $1^{\text {st }}$ edn. (London and New Haven: William Hodge and Yale University Press).

Mitra, Anirban, Mitra, Shabana and Mukherji, Arnab (2017) Cash for Votes: Evidence from India, University of Kent School of Economics Discussion Papers, KDPE 1711.

North, Douglass C. (1977) 'Markets and Other Allocation Systems in History: The Challenge of Karl Polanyi', Journal of European Economic History, 6(3), Winter, pp. 703-16.

North, Douglass C. (1990a) Institutions, Institutional Change and Economic Performance (Cambridge and New York: Cambridge University Press).

North, Douglass C. (1990b) 'A Transactions Cost Theory of Politics', Journal of Theoretical Politics, 2(4), October, pp. 355-67.

O’Neill, John (1998) The Market: Ethics, Knowledge and Politics (London and New York: Routledge).

Ostrom, Elinor (1990) Governing the Commons: The Evolution of Institutions for Collective Action (Cambridge: Cambridge University Press).

Pagano, Ugo (2014) 'The Crisis of Intellectual Monopoly Capitalism', Cambridge Journal of Economics, 38(6), November, pp. 1409-29.

Pantaleoni, Maffeo (1911) 'Considerazioni sulle proprieta di un sistema di prezzi politici', Giornale degli Economisti, 42, pp. 9-29, 114-33.

Pejovich, Svetozar (1994) 'The Market for Institutions vs. Capitalism by Fiat: The Case of Eastern Europe', Kyklos, 47(4), pp. 519-29.

Pettman, Ralph (2001) World Politics: Rationalism and Beyond (London: Palgrave Macmillan).

Polanyi, Karl (1944) The Great Transformation: The Political and Economic Origins of Our Time (New York: Rinehart).

Polanyi, Karl (1977) The Livelihood of Man, ed. Harry W. Pearson (New York: Academic Press).

Polanyi, Michael (1944) 'Patent Reform', Review of Economic Studies, 11(2), Summer, pp. 61-76.

Polanyi, Michael (1962) 'The Republic of Science: Its Political and Economic Theory', Minerva, 1, pp. 54-73.

Posner, Richard A. (1994) Sex and Reason (Cambridge, MA: Harvard University Press).

Putnam, Hilary (2002) The Collapse of the Fact/Value Dichotomy and Other Essays (Cambridge, MA: Harvard University Press).

Putnam, Robert D. (2000) Bowling Alone: The Collapse and Revival of American Community (New York: Simon and Schuster).

Radin, Margaret Jane (1996) Contested Commodities: Trouble with Trade in Sex, Children, Body Parts and Other Things (Cambridge, MA: Harvard University Press).

Rosenbaum, Eckehard F. (2000) 'What is a Market? On the Methodology of a Contested Concept', Review of Social Economy, 58(4), December, pp. 455-82. 
Russell, Bertrand (1923) 'Vagueness', Australasian Journal of Psychology and Philosophy, 1(1), pp. 84-92.

Sandel, Michael (2012) What Money Can't Buy: The Moral Limits of Markets (London: Allen Lane).

Satz, Debra (2010) Why Some Things Should not be for Sale: The Moral Limits of Markets (Oxford and New York: Oxford University Press).

Schelling, Thomas C. (1984) 'Economics and Criminal Enterprise', in Schelling, Thomas C. (1980) Choice and Consequence: Perspectives of an Errant Economist (Cambridge MA: Harvard University Press), pp. 179-94.

Simmel, Georg (2004) The Philosophy of Money, translated from the 2nd. German edition of 1907 by Tom Bottomore and David Frisby (London and New York: Routledge).

Soros, George (1998) The Crisis of Global Capitalism: Open Society Endangered (New York: Public Affairs).

Soros, George (2008) The New Paradigm for Financial Markets: The Credit Crisis of 2008 and What It Means (New York: Public Affairs).

Stedman Jones, Daniel (2012) Masters of the Universe: Hayek, Friedman, and the Birth of Neoliberal Politics (Princeton: Princeton University Press).

Stiglitz, Joseph E. (2008) 'The Fall of Wall Street Is to Market Fundamentalism What the Fall of the Berlin Wall Was to Communism', Interview with Nathan Gardels, The Huffington Post, September $16^{\text {th }}$ 2008. http://www.huffingtonpost.com/nathan-gardels/stiglitz-the-fallof-wall_b_126911.html. Accessed 10 July 2017.

Thelen, Kathleen (2004) How Institutions Evolve: The Political Economy of Skills in Germany, Britain, the United States and Japan (Cambridge and New York: Cambridge University Press).

Thornton, Mark (1991) The Economics of Prohibition (Salt Lake City: University of Utah Press).

Tyler, Tom R. (1990) Why People Obey the Law (New Haven: Yale University Press).

US Supreme Court (1969) 'Red Lion Broadcasting Co., Inc. v. FCC, 395 U.S. 367', Justia, 9 June. https://supreme.justia.com/cases/federal/us/395/367/case.html. Retrieved 5 December 2017.

Venugopal, Rajesh (2015) 'Neoliberalism as a Concept', Economy and Society, 44(2), pp. 165-87.

Walzer, Michael (1983) Spheres of Justice: A Defence of Pluralism and Equality (New York: Basic Books).

Weber, Max (1968) Economy and Society: An Outline of Interpretative Sociology, 2 vols, translated from the German edition of 1921-1922 by G. Roth and C. Wittich (Berkeley: University of California Press). 